\title{
Production of haemolysis and its correlation with enterotoxicity in Aeromonas spp.
}

\author{
D. V. SINGH and S. C. SANYAL
}

Department of Microbiology, Institute of Medical Sciences, Banaras Hindu University, Varanasi 221 005, India

\begin{abstract}
Summary. A total of 147 clinical and environmental isolates of Aeromonas that included 14 A. hydrophila, $60 \mathrm{~A}$. sobria and $73 \mathrm{~A}$. caviae strains was tested for haemolysin production and its correlation with enterotoxicity; 108 isolates produced $\beta$-haemolysis. For $A$. hydrophila and A. sobria, titres of haemolysin were 16-128 HU/ml and for $A$. caviae, $16-64 \mathrm{HU} / \mathrm{ml}$. In the ileal loop test, $82(55.8 \%)$ strains of Aeromonas spp. produced enterotoxin. Of the $\beta$ haemolytic strains, $72.7 \%$ of $A$. hydrophila, $58.6 \%$ of $A$. sobria and $68.6 \%$ of $A$. caviae isolates caused fluid accumulation in rabbit ileal loops. One strain each of $\alpha$-haemolytic $A$. sobria and $A$. caviae, one of non-haemolytic $A$. sobria and nine of non-haemolytic $A$. caviae also caused a secretory response. The $\beta$-haemolytic strains caused significantly more $(p<0.05)$ fluid accumulation than the $\alpha$ - and non-haemolytic isolates regardless of their species designation. The remaining $65(44.2 \%)$ isolates belonging to the three species included $\alpha-, \beta$ - and non-haemolytic strains: they failed to cause fluid accumulation in the initial experiments but did so after one to three consecutive passages through rabbit ileal loops. Two $\alpha$-and 13 non-haemolytic strains switched to production of $\beta$-haemolysis when they showed positive ileal loop reactions. However, on repeated subcultures or on storage in the laboratory, all of them reverted to their original haemolytic character and no longer produced enterotoxic activity.
\end{abstract}

\section{Introduction}

Aeromonas hydrophila has been reported as an aetiological agent of diarrhoea in man. ${ }^{1-16}$ Production of heat labile enterotoxin by strains of Aeromonas was first demonstrated in an adult rabbit ileal loop (RIL) model. ${ }^{4,6,7,17}$ Subsequently, enterotoxin production by strains of Aeromonas was demonstrated in other animal and tissue-culture assays. ${ }^{15-21} A$. hydrophila and $A$. sobria have been reported to produce extracellular products such as haemolysin, ${ }^{15,16,22,23}$ aerolysin, ${ }^{24}$ cytotoxin ${ }^{9,15}$ and various enzymes. ${ }^{25-27}$ It has been reported that enterotoxic strains of Aeromonas spp. are $\beta$-haemolytic. ${ }^{14-16,28-32}$ Most of these $\beta$ haemolytic strains were either $A$. hydrophila or $A$. sobria but rarely $A$. caviae. ${ }^{14-16,28,30,32-34}$ Earlier studies indicated that enterotoxic and haemolytic properties of Aeromonas spp. were different entities ${ }^{\mathbf{3 4}}$ and were determined by separate genes located on different segments of the chromosome. ${ }^{35}$ Aeromonas strains that caused little or no accumulation of fluid in the initial test were reported to switch to production of enterotoxin after consecutive passages through rabbit ileal loops. ${ }^{4,6.7}$ However, no such effect of passage on the haemolytic character of this organism has yet been reported. The present study was undertaken to test for

Received 26 April 1991; revised version received 7 Dec. 1991; accepted 10 Jan. 1992. the production of haemolysis and enterotoxin by different species of Aeromonas, to look for any correlation between haemolytic and enterotoxic activities, and to test for changes in haemolytic character of strains showing enterotoxin production after passage through rabbit ileal loops.

\section{Materials and methods}

\section{Bacterial strains}

A total of 147 isolates of Aeromonas was included in the study. They were isolated from children and adults with diarrhoea (54), water from shallow tube wells (6), dug wells (6), the piped water supply (6), from sewage (6) and the river Ganga (20), and from superficial skin ulcers of fish (49). The organisms were identified by the method of Popoff ${ }^{36}$ as $A$. hydrophila (14), A sobria (60) and $A$. caviae (73). Strains were maintained in peptone agar stab cultures at room temperature and did not undergo more than three subcultures before testing for haemolysis and enterotoxin production.

\section{Preparation of culture filtrates for haemolysin and enterotoxin detection}

Culture filtrates of isolates that gave ileal loop reactions in initial tests with whole live cells were 
Table I. Haemolytic activity of CFs of strains of Aeromonas before and after passage through rabbit ileal loops

\begin{tabular}{ccccc}
\hline $\begin{array}{c}\text { Species and } \\
\text { haemolytic } \\
\text { character } \\
\text { (number of } \\
\text { isolates) }\end{array}$ & $\begin{array}{c}\text { Number (\%) } \\
\text { tested before } \\
\text { passage }\end{array}$ & $\begin{array}{c}\text { Haemolysin } \\
\text { production } \\
(\mathrm{HU} / \mathrm{ml})\end{array}$ & $\begin{array}{c}\text { Number } \\
\text { tested } \\
\text { after } \\
\text { passage* }\end{array}$ & $\begin{array}{c}\text { Haemolysin } \\
\text { production } \\
(\mathrm{HU} / \mathrm{ml})\end{array}$ \\
\hline $\begin{array}{c}A \text {. hydrophila }(14) \\
\beta \text {-haemolytic }\end{array}$ & $11(78 \cdot 5)$ & $16-128$ & 0 & $\ldots$ \\
$\begin{array}{c}\text { non-haemolytic } \\
\begin{array}{c}\text { sobria }(60) \\
\alpha \text {-haemolytic }\end{array}\end{array}$ & $3(21 \cdot 4)$ & $\ldots$ & 3 & $16-128$ \\
$\begin{array}{c}\beta \text {-haemolytic } \\
\text { non-haemolytic }\end{array}$ & $6(10 \cdot 0)$ & $\ldots$ & 5 & $16-128$ \\
$\begin{array}{c}A \text {. caviae (73) } \\
\alpha \text {-haemolytic } \\
\beta \text {-haemolytic } \\
\text { non-haemolytic }\end{array}$ & $8(16 \cdot 7)$ & $16-128$ & 0 & $\ldots$ \\
\hline
\end{tabular}

* Non- $\beta$-haemolytic strains tested only after passage.

prepared by the method of Annapurna and Sanyal. Briefly, $10 \mathrm{ml}$ of Brain Heart Infusion Broth (BHIB; Difco) in a 50-ml conical flask was inoculated with five or six smooth colonies grown overnight on nutrient agar (NA). The flasks were incubated at $37^{\circ} \mathrm{C}$ in a water bath with shaking for $16-18 \mathrm{~h}$ with $80-120$ oscillations $/ \mathrm{min}$. The cultures were centrifuged at $22000 \mathrm{~g}$ for $20 \mathrm{~min}$ at $4^{\circ} \mathrm{C}$, and supernates were filtered through membrane filters (Millipore; $0.22 \mu \mathrm{m}$ ) and stored at $4^{\circ} \mathrm{C}$. These culture filtrates (CFs) were used for haemolysin and enterotoxin assays. $\alpha$-Haemolytic strains were grown at $25^{\circ} \mathrm{C}$ for $48 \mathrm{~h}$ for preparation of $\mathrm{CFs}$ because maximum production of this haemolysin takes place at this temperature. ${ }^{22}$

\section{Detection of haemolysis and titration of haemolysin}

Haemolysin production by Aeromonas strains was tested on sheep blood agar ( $5 \%$ ) with a $4-5 \mathrm{~h}$ culture of each organism in BHIB. After incubation for $24 \mathrm{~h}$ at $37^{\circ} \mathrm{C}$, the plates were examined for the presence of $\alpha$ or $\beta$-haemolysis around the colonies. The production of haemolysin(s) by each strain was confirmed by the method of Smith ${ }^{37}$ as modified by Rennie and Arbuthnott. ${ }^{38}$ Briefly, sheep erythrocytes (SRBC) were washed three times in isotonic saline and a $2 \%$ suspension was prepared in $0.04 \mathrm{~m}$ phosphate buffered saline (PBS, pH 7.4). Haemolytic activity was determined by mixing $0.5 \mathrm{ml}$ of two-fold serial dilutions of $\mathrm{CF}$ of each strain with an equal volume of SRBC $2 \%$ suspension, incubated at $37^{\circ} \mathrm{C}$ in a water bath for $2 \mathrm{~h}$ and left at $4^{\circ} \mathrm{C}$ for $12 \mathrm{~h}$. The lysed portion was diluted four-fold with sterile normal saline and the optical density at $540 \mathrm{~nm}$ was measured in a colorimeter. Standardisation of the erythrocyte suspension was done by lysis of $0.5 \mathrm{ml}$ of SRBC $2 \%$ with a few crystals of saponin. An optical density of 0.5 at $540 \mathrm{~nm}$ was considered to indicate a standardised SRBC $2 \%$. The negative control was $0.5 \mathrm{ml}$ of saline instead of $\mathrm{CF}$. One haemolytic unit (HU) was defined as the amount of CF that caused $50 \%$ haemolysis under experimental conditions.

\section{Ileal loop test and passage through rabbit ileal loops}

Cultures and CFs of the 147 strains of Aeromonas spp. were tested in adult albino rabbits (Belgian strain) by the method of De and Chatterjee ${ }^{39}$ as modified by Annapurna and Sanyal ${ }^{6}$ for detection of enterotoxin production. Briefly, bacteria grown in BHIB for $3 \mathrm{~h}$ were diluted 10-fold in the same medium and inoculated into rabbit ileal loops in 1-ml doses containing $10^{5}-10^{6} \mathrm{cfu}$. A BHIB culture of toxigenic strain $569 \mathrm{~B}$ of $V$. cholerae was used as a positive control and unseeded BHIB as a negative control. CF $(1 \mathrm{ml})$ was tested in the same way. Each test was done in three rabbits. Rabbits were killed after $6 \mathrm{~h}$.

Strains of Aeromonas that caused little or no accumulation of fluid in the initial tests were passaged through rabbit ileal loops according to the method of Sanyal et al. ${ }^{40,41}$ Briefly, each strain was cultured aseptically from a rabbit ileal loop on NA and incubated overnight; five or six colonies were inoculated into BHIB and incubated for $3 \mathrm{~h}$, and $1 \mathrm{ml}$ of diluted culture was inoculated again into a rabbit ileal loop. The process was continued until a positive response was obtained.

\section{Results}

The majority (108 of 147) of isolates-11 $(78.5 \%)$ of A. hydrophila, 46 (76.7\%) of $A$. sobria and $51(69.9 \%)$ of $A$. caviae-produced $\beta$-haemolysis on sheep blood $5 \%$ agar (table I). $\alpha$-Haemolysis was shown by only eight strains comprising six $(10 \%)$ of $A$. sobria and two $(2 \cdot 7 \%)$ of $A$. caviae. Thirty-one strains were nonhaemolytic including three $(21.4 \%)$ of $A$. hydrophila, eight (13.3\%) of A. sobria and $20(27.4 \%)$ of A. caviae.

When CFs were tested for haemolytic activity, only those causing $\beta$-haemolysis on sheep blood agar plates showed lysis of $2 \%$ sheep erythrocytes (table I). The 
Table II. Correlation between enterotoxic and haemolytic activities of Aeromonas strains

\begin{tabular}{|c|c|c|c|c|c|}
\hline $\begin{array}{l}\text { Species and } \\
\text { haemolytic } \\
\text { character }\end{array}$ & $\begin{array}{l}\text { Number of } \\
\text { strains } \\
\text { tested }\end{array}$ & $\begin{array}{l}\text { Number showing } \\
\text { fluid accumulation } \\
\text { before passage }\end{array}$ & $\begin{array}{c}\text { Fluid } \\
\text { accumulated } \\
\text { (ml/cm of gut) }\end{array}$ & $\begin{array}{l}\text { Number showing } \\
\text { fluid accumulation } \\
\text { after passage* }\end{array}$ & $\begin{array}{c}\text { Fluid } \\
\text { accumulated } \\
\text { (ml/cm of gut) }\end{array}$ \\
\hline \multicolumn{6}{|l|}{ A. hydrophila } \\
\hline$\beta$-haemolytic & 11 & $8(72 \cdot 7)$ & $0.5-1.7$ & $3(27 \cdot 3)$ & $0.7-1.4$ \\
\hline non-haemolytic & 3 & $0(0)$ & $\ldots$ & $3(100 \cdot 0)$ & $1 \cdot 0-1 \cdot 5$ \\
\hline \multicolumn{6}{|l|}{ A. sobria } \\
\hline$\alpha$-haemolytic & 6 & $1(16 \cdot 7)$ & 0.5 & $5(83 \cdot 3)$ & $0.5-1.0$ \\
\hline$\beta$-haemolytic & 46 & $27(58 \cdot 6)$ & $0 \cdot 6-1 \cdot 3$ & $19(41 \cdot 4)$ & $0.6-1.5$ \\
\hline non-haemolytic & 8 & $1(12 \cdot 5)$ & 0.4 & $7(87 \cdot 5)$ & $0.5-1.4$ \\
\hline \multicolumn{6}{|l|}{ A. caviae } \\
\hline$\alpha$-haemolytic & 2 & $1(50 \cdot 0)$ & 0.5 & $1(50 \cdot 0)$ & $0.5-1.0$ \\
\hline$\beta$-haemolytic & 51 & $35(68.6)$ & $0.5-1.0$ & $16(31.4)$ & $0.6-1 \cdot 2$ \\
\hline non-haemolytic & 20 & $9(45 \cdot 0)$ & $0.4-0.8$ & $11(55 \cdot 0)$ & $0.5-1.0$ \\
\hline Total & 147 & $82(55.8)$ & $\ldots$ & $65(44 \cdot 2)$ & $\ldots$ \\
\hline
\end{tabular}

Figures in parentheses are percentages of total number of strains tested.

* One to three passages in rabbit ileal loops.

titres of haemolytic activity produced by $A$. hydrophila and $A$. sobria isolates were $16-128 \mathrm{HU} / \mathrm{ml}$ and by $A$. caviae isolates, $16-64 \mathrm{HU} / \mathrm{ml}$ (table I).

Cultures and CFs of $82(55.8 \%)$ of the Aeromonas strains tested caused accumulation of fluid in the rabbit ileal loop in the initial set of experiments. Amongst the $\beta$-haemolytic strains, eight (72.7\%) of $A$. hydrophila, $27(58.6 \%)$ of $A$. sobria and $35(68.6 \%)$ of $A$. caviae caused fluid accumulation (table II). A single strain each of $\alpha$-haemolytic $A$. sobria and $A$. caviae isolates also showed this activity. Of the non-haemolytic strains, one $A$. sobria and nine $A$. caviae isolates caused a secretory response in rabbit ileal loops (table II).

The $\beta$-haemolytic strains of Aeromonas caused significantly more ( $\mathrm{p}<0.05$, Student's $t$ test) fluid accumulation in rabbit ileal loops than the $\alpha$ - or non-

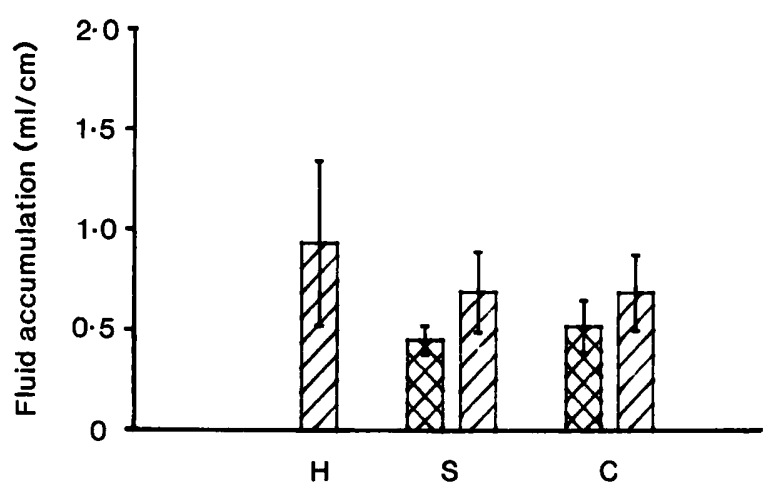

Figure. Enterotoxicity of $\beta$-haemolytic $(\square)$ and $\alpha$-or non-haemolytic (ख) strains of Aeromonas without animal passage: H, A. hydrophila (eight strains); S, A. sobria (29 strains); C, A. caviae (45 strains).

Table III. Effects of passage on fluid accumulation and changes in haemolytic character of Aeromonas strains

\begin{tabular}{|c|c|c|c|c|c|c|}
\hline \multirow[t]{2}{*}{ Species } & \multirow[t]{2}{*}{ Strain } & \multirow{2}{*}{$\begin{array}{l}\text { Haemolytic } \\
\text { type }\end{array}$} & \multicolumn{4}{|c|}{$\begin{array}{l}\text { Fluid accumulation }(\mathrm{ml} / \mathrm{cm}) \\
\text { after passage no. }\end{array}$} \\
\hline & & & 0 & 1 & 2 & 3 \\
\hline \multirow[t]{3}{*}{ A. hydrophila } & D-5485 & Non & ND & ND & ND & $1.4^{*}$ \\
\hline & F-10 & Non & ND & ND & $1.5^{*}$ & 1.6 \\
\hline & F-67 & Non & ND & ND & $1.0^{*}$ & 1.2 \\
\hline \multirow[t]{5}{*}{ A. sorbria } & D-5 & $\alpha$ & ND & ND & $0.44^{*}$ & 0.6 \\
\hline & D-72 & Non & ND & $\mathrm{ND}^{*}$ & 0.44 & 0.6 \\
\hline & W-38 & Non & ND & $0.5^{*}$ & 0.6 & 0.8 \\
\hline & W-16 & Non & ND & $0.7^{*}$ & 0.8 & 0.9 \\
\hline & F-36 & Non & ND & $0.6^{*}$ & 0.75 & 0.9 \\
\hline \multirow[t]{9}{*}{ A. caviae } & D-42 & Non & 0.4 & $0.8^{*}$ & 0.95 & $1 \cdot 1$ \\
\hline & D-421 & Non & ND & $0.65^{*}$ & 0.78 & 0.94 \\
\hline & D-425 & Non & ND & $0.55^{*}$ & 0.75 & 1.0 \\
\hline & W-3 & Non & ND & $0.4^{*}$ & 0.85 & 1.0 \\
\hline & W-9 & Non & ND & $0.6^{*}$ & 0.7 & 0.85 \\
\hline & F-51 & Non & 0.4 & $0.6^{*}$ & 0.7 & 0.85 \\
\hline & F-19 & $\alpha$ & ND & $0.65^{*}$ & 0.78 & 0.94 \\
\hline & F-61 & $\beta$ & ND* & 0.55 & 0.75 & 0.95 \\
\hline & F-75 & $\beta$ & $\mathrm{ND}^{*}$ & ND & ND & 0.65 \\
\hline
\end{tabular}

ND, not detected (lower limit for detection $0.2 \mathrm{ml} / \mathrm{cm}$ ).

Sources of isolates: D, diarrhoeal; W, water; F, fish.

* Change to haemolysis detected. 
Table IV. Enhancement of titres of haemolysin of Aeromonas strains after passage through rabbit ileal loops

\begin{tabular}{|c|c|c|c|c|c|c|}
\hline \multirow{2}{*}{ Species } & \multirow{2}{*}{ Strain } & \multirow{2}{*}{$\begin{array}{l}\text { Haemolytic } \\
\text { type }\end{array}$} & \multicolumn{4}{|c|}{$\begin{array}{l}\text { Hamolysin titres }(\mathrm{HU} / \mathrm{ml}) \\
\text { after passage no. }\end{array}$} \\
\hline & & & 0 & 1 & 2 & 3 \\
\hline \multirow[t]{3}{*}{ A. hydrophila } & D-5485 & Non & $\ldots$ & $\ldots$ & $\ldots$ & 128 \\
\hline & F-10 & Non & $\ldots$ & $\ldots$ & $32 *$ & 64 \\
\hline & F-67 & Non & $\ldots$ & $\ldots$ & $16^{*}$ & 64 \\
\hline \multirow[t]{5}{*}{ A. sorbria } & D-5 & $\alpha$ & $\ldots$ & $\ldots$ & $16^{*}$ & 64 \\
\hline & D-72 & Non & $\ldots$ & 16 & $32 *$ & 64 \\
\hline & W-38 & Non & $\ldots$ & $32^{*}$ & 64 & 128 \\
\hline & W-16 & Non & $\ldots$ & $64^{*}$ & 128 & 256 \\
\hline & F-36 & Non & ... & $64^{*}$ & 128 & 256 \\
\hline \multirow[t]{9}{*}{ A. caviae } & D-42 & Non & $\mathrm{ND}^{*}$ & 32 & 64 & 128 \\
\hline & D-42I & Non & $\ldots$ & $32^{*}$ & 128 & 256 \\
\hline & D-425 & Non & $\begin{array}{l}\cdots \\
\cdots\end{array}$ & $32 *$ & 64 & 128 \\
\hline & W-3 & Non & $\ldots$ & $16^{*}$ & 32 & 128 \\
\hline & W-9 & Non & $\ldots$ & $32 *$ & 64 & 128 \\
\hline & F-51 & Non & ND* & 32 & 64 & 128 \\
\hline & F-19 & $\alpha$ & 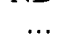 & $16^{*}$ & 32 & 128 \\
\hline & F-61 & $\beta$ & 16 & $32 *$ & 64 & 128 \\
\hline & F-75 & $\beta$ & 16 & 32 & 64 & $128^{*}$ \\
\hline
\end{tabular}

ND, not detected ; ..., not tested.

Sources of isolates: D, diarrhoeal; $\mathrm{W}$, water; F, fish.

* Enterotoxin produced.

haemolytic isolates, regardless of their species designation and source of isolation (figure).

After one to three consecutive passages through rabbit ileal loops, all $65(44.2 \%)$ Aeromonas strains that caused little or no accumulation of fluid in the initial experiments did so (table II).

Thirteen non-haemolytic and two each of $\alpha$ - and $\beta$ haemolytic strains showed a marked increase in fluid accumulation on each consecutive passage through rabbit ileal loops. The non-haemolytic and $\alpha$-haemolytic strains switched over to the production of $\beta$ haemolysis when they showed a positive ileal loop reaction (table III) and the titres of haemolysin also increased on each consecutive passage (table IV). However, on storage for 2-3 weeks in peptone agar stab cultures at room temperature, or on repeated subculture, all the strains reverted to their original haemolytic characters (either $\alpha$ - or non-haemolytic), and no longer produced enterotoxic activity.

\section{Discussion}

The majority of the strains of Aeromonas in this study produced $\beta$-haemolysis and this property was not limited to $A$. hydrophila and $A$. sobria but extended to $A$. caviae in almost equal proportion. This phenomenon may be explained by the genetic evidence that sequences homologous to the $\beta$-haemolysin gene are present in all species of Aeromonas including $A$. caviae. ${ }^{42}$ Furthermore, $\beta$-haemolysin in Aeromonas spp. has been suggested to be a cytotoxin $;^{15,42,43}$ a recent report on the cytotoxicity of $A$. caviae strains indicates that most of them possess this property and the failure by earlier workers to detect this was probably due to the use of medium containing higher levels of glucose, which has deleterious effects on the organism. ${ }^{44}$

Several workers have shown that enterotoxin is produced by most $\beta$-haemolytic strains of Aeromonas. ${ }^{14,15,28,30,45-47}$ However, the results of the present study indicate that a significant number of $\beta$ haemolytic strains $(35 \%)$ did not show any enterotoxic activity when first tested $(p<0.05)$. In addition, two of the eight $\alpha$-haemolytic and 10 of the 31 non-haemolytic strains of $A$. sobria and $A$. caviae also produced enterotoxin in the initial tests. However, the $\beta$ haemolytic strains showed significantly more enterotoxic activity than the $\alpha$ - and non-haemolytic strains, independently of their species designation. Figura et $a l .{ }^{48}$ and Eko and Utsalo ${ }^{33}$ also encountered a few enterotoxic non-haemolytic and non-toxic $\beta$-haemolytic strains in their studies. Thus, this study clearly demonstrates that the capacity for enterotoxin production in Aeromonas spp. is not confined only to the $\beta$-haemolytic trains but that the $\alpha$-and non-haemolytic isolates also possess this property, although to a lesser extent.

All of the Aeromonas strains that failed to produce enterotoxin in the initial set of experiments $(44.2 \%)$ produced the toxin after one to three consecutive passages through rabbit ileal loops, suggesting that all Aeromonas strains are potentially enterotoxic regardless of their species designation, source of isolation and type of haemolysin produced. Similar observations on switching to toxin production by a non-toxigenic strain on consecutive passage through a susceptible host were also made in our earlier studies with Aeromonas spp. and other enteropathogenic organisms. ${ }^{6,7,40,41,49-53}$ Such a change may result from the existence of a repression-derepression phenomenon controlling expression of a toxin gene depending on a 
particular micro-environment ${ }^{54}$ such as occurs in Vibrio cholerae.

The observation that $\alpha$ - and non-haemolytic strains of Aeromonas switched to production of $\beta$-haemolysis after one to three consecutive passages through rabbit ileal loops, along with initiation of fluid secretion, indicates that this process may influence the control of $\beta$-haemolysin and toxin production. Moreover, the titres of haemolysin elaborated in the CFs increased with each passage. One non-haemolytic strain converted to $\beta$-haemolysin production after a single passage without any secretory effect. However, on the second passage the strain caused accumulation of fluid. These observations indicate that a repression and de-repression phenomenon may also be operative

\section{References}

1. von Graevenitz A, Mensch AH. The genus Aeromonas in human bacteriology. Report of 30 cases and review of the literature. New Engl J Med 1968; 278: 245-249.

2. Zajc-Satler J. Morphological and biochemical studies of 27 strains belonging to the genus Aeromonas isolated from clinical sources. J Med Microbiol 1972; 5: 263-265.

3. Sanyal SC, Gaur SD, Srivastava DL, Sen PC, Marwah SM, Singh H. Enteric infections in Sunderpur slum area. Indian $J$ Med Res 1972; 60: 979-986

4. Sanyal SC, Singh SJ, Sen PC. Enterotoxigenicity of Aeromonas hydrophila and Plesiomonas shigelloides. J Med Microbiol 1975; 8: 195-198.

5. Sanyal SC, Sen PC, Tiwari IC, Bhatia BD, Singh SJ. Microbiological agents in stools of infants and young children with and without acute diarrhoeal disease. J Trop Med Hyg $1977 ; 80: 2-8$.

6. Annapurna E, Sanyal SC. Studies on enteropathogenicity of Aeromonas hydrophila in an experimental model. Indian $J$ Prev Soc Med 1975; 6: 234-237.

7. Annapurna E, Sanyal SC. Enterotoxigenicity of Aeromonas hydrophila. J Med Microbiol 1977; 10 : 317-323.

8. Chatterjee BD, Neogy KN. Studies of Aeromonas and Plesiomonas species isolated from cases of cholereic diarrhoea. Indian J Med Res 1972; 60: 520-524.

9. Cumberbatch N, Gurwith MJ, Langston C, Sack RB, Brunton JL. Cytotoxic enterotoxin produced by Aeromonas hydrophila; relationship of toxigenic isolates to diarrhoeal diseases. Infect Immun 1979; 23: 829-837.

10. Gracey M, Burke V, Robinson J. Aeromonas-associated gastroenteritis. Lancet 1982; 2: 1304-1306.

11. Pitarangsi C, Echeverria P, Whitmire R et al. Enteropathogenicity of Aeromonas hydrophila and Plesiomonas shigelloides; prevalence among individuals with and without diarrhea in Thailand. Infect Immun 1982; 35: 666-673.

12. Janda JM, Bottone EJ, Reitano M. Aeromonas species in clinical microbiology: significance, epidemiology and speciation. Diagn Microbiol Infect Dis 1983; 1: 221-228.

13. Holmberg SD, Farmer JJ. Aeromonas hydrophila and Plesiomonas shigelloides as cases of intestinal infections. Rev Infect Dis 1984; 6: 633-639.

14. Turnbull PCB, Lee JV, Miliotis MD et al. Enterotoxin production in relation to taxonomic grouping and source of isolation of Aeromonas species. J Clin Microbiol 1984; 19: $175-180$.

15. Barer MR, Millership SE, Tabaqchali S. Relationship of toxin production to species in the genus Aeromonas. $\mathrm{J} \mathrm{Med}$ Microbiol 1986; 22: 303-309.

16. Kuijper EJ, Steigerwalt AG, Schoenmakers BSCIM, Peeters MF, Zanen HC, Brenner DJ. Phenotypic characterization and DNA relatedness in human fecal isolates of Aeromonas spp. J Clin Microbiol 1989; 27: 132-138.

17. Ljungh A, Popoff M, Wadström T. Aeromonas hydrophila in acute diarrheal disease: detection of enterotoxin and biotyping of strains. J Clin Microbiol 1977; 6: 96-100. in the case of the $\beta$-haemolysin gene and that the rabbit ileal loop provides a micro-environment conducive to its expression; this is confirmed by reversion of these strains to their original $\alpha$ - and non-haemolytic characters. These data indicate that all Aeromonas strains, irrespective of their species designation and source of isolation, possess a $\beta$-haemolysin gene and may elicit a secretory response in the gut. Passage through the gut of a susceptible host probably controls the expression of $\beta$-haemolysin and enterotoxin production.

This study was supported by the Council of Scientific and Industrial Research, New Delhi in the form of a Fellowship to D.V.S. and by the Indian Council of Medical Research, New Delhi grant no. 5/8-1/(49)/88 ECD/II. We gratefully acknowledge the secretarial assistance of $\mathrm{Mr} \mathrm{D}$. Venu Gopal.

18. Dubey RS, Sanyal SC. Enterotoxicity of Aeromonas hydrophila skin responses and in vitro neutralisation. Zentralbl Bakteriol Orig A 1978; 242: 487-499.

19. Dubey RS, Bhattacharya AK, Sanyal SC. Elevation of adenosine 3' 5 ' cyclic monophosphate level by Aeromonas hydrophila enterotoxin. Indian J Med Res 1981; 74: 668-674.

20. Burke V, Robinson J, Berry RJ, Gracey M. Detection of enterotoxins of Aeromonas hydrophila by a suckling-mouse test. J Med Microbiol 1981; 14: 401-408.

21. Chakraborty T, Montenegro MA, Sanyal SC, Helmuth R, Bulling E, Timmis KN. Cloning of enterotoxin gene from Aeromonas hydrophila provides conclusive evidence of production of a cytotonic enterotoxin. Infect Immun 1984; 46: 435-441.

22. Ljungh A, Wadstrom T. Aeromonas toxins. In: Dorner F, Drews J (eds) Pharmacology of bacterial toxins. Oxford, Pergamon Press. 1986: 289-305.

23. Monfort P, Baleux B. Distribution of Aeromonas hydrophila, $A$. caviae and $A$. sobria in aquatic environments, frequency of extracellular haemolysin among these three species. $J$ Diarrhoeal Dis Res 1988; 2: 138-139.

24. Bernheimer AW, Avigad LS. Partial characterization of aerolysin, a lytic exotoxin from Aeromonas hydrophila. Infect Immun 1974; 9: 1016-1021.

25. Boulanger Y, Lallier R, Cousineau G. Isolation of enterotoxigenic Aeromonas from fish. Can J Microbiol 1977; 23 1161-1164.

26. Daily OP, Joseph SW, Coolbaugh JC et al. Association of Aeromonas sobria with human infection. $J$ Clin Microbiol 1981; 13: 769-777.

27. Janda JM. Biochemical and exoenzymatic properties of Aeromonas species. Diagn Microbiol Infect Dis 1985; 3: 223-232.

28. Burke V, Robinson J, Atkinson HM, Gracey M. Biochemical characteristics of enterotoxigenic Aeromonas spp. J Clin Microbiol 1982; 15: 48-52.

29. Burke V, Gracey M, Robinson J, Peck D, Beaman J, Bundell C. The microbiology of childhood gastroenteritis: Aeromonas species and other infective agents. $J$ Infect Dis $1983 ; 148$ : 68-74.

30. Burke V, Robinson J, Beaman $\mathrm{J}$ et al. Correlation of enterotoxicity with biotype in Aeromonas spp. J Clin Microbiol 1983; 18: 1196-1200.

31. Janda JM. Biochemical and exoenzymatic properties of Aeromonas species. Diagn Microbiol Infect Dis 1985; 3: 223-232.

32. Majeed KN, Egan AF, MacRae IC. Incidence of aeromonads in samples from an abattoir processing lambs. J Appl Bacteriol 1989; 67: 597-604.

33. Eko OF, Utsalo SJ. Characterization and significance of Aeromonas spp. isolated from diarrhoeic stools in Nigeria. J Trop Med Hyg 1989; 92: 97-101.

34. Dubey RS, Sanyal SC, Malhotra OP. Purification of Aeromonas hydrophila enterotoxin and its mode of action in experimental model. In: Eaker D, Wadstrom T (eds) Natural toxins. Pergamon Press. 1980: 259-268.

35. Chakraborty T, Huhle B, Bergbauer H, Goebel W. Cloning, 
expression, and mapping of the Aeromonas hydrophila aerolysin gene determinant in Escherichia coli K-12. $J$ Bacteriol 1986; 167: 368-374.

36. Popoff M. Genus III. Aeromonas Kluyver and Van Neil 1936. In: Kreig NR, Holt SG (eds) Bergey's Manual of systematic bacteriology, 9th edn. Baltimore, Williams and Wilkins Co. 1984: 545-548.

37. Smith HW. Haemolysins of Escherichia coli.J Pathol Bacteriol 1963; 85: 197-211.

38. Rennie RP, Arbuthnott JP. Partial characterisation of Escherichia coli haemolysin. J Med Microbiol 1974; 7 : 179-188.

39. De SN, Chatterjee DN. Experimental study of mechanism of action of Vibrio cholerae on intestinal mucous membrane. $J$ Pathol Bacteriol 1953; 66: 559-562.

40. Sanyal SC, Huq MI, Neogy PKB, Alam K, Kabir MI, Rahaman AS. Experimental studies on the pathogenicity of Vibrio mimicus strains isolated in Bangladesh. Aust J Exp Med Medical Sci 1984; 62: 515-521.

41. Sanyal SC, Neogy PKB, Alam K, Huq MI, Al-Mahmud KA. A new enterotoxin produced by Vibrio cholerae O1. J Diarrhoeal Dis Res 1984; 2: 3-12.

42. Husslein V, Notermans SHE, Chakraborty T. Gene probes for the detection of areolysin in Aeromonas spp. $J$ Diarrhoeal Dis Res 1988; 6: 124-130.

43. Ljungh A, Wretlind B, Mollby R. Separation and characterization of enterotoxin and two haemolysins from Aeromonas hydrophila. Acta Pathol Microbiol Scand (Sect B) $1981 ; 89,387-397$.

44. Namdari H, Bottone EJ. Cytotoxin and enterotoxin production as factors delineating enteropathogenicity of Aeromonas caviae. J Clin Microbiol 1989; 28: 1796-1798.

45. Seidler RJ, Allen DA, Lockman H, Colwell RR, Joseph SW,
Daily OP. Isolation, enumeration, and characterization of Aeromonas from polluted waters encountered in diving operations. Appl Environ Microbiol 1980; 39: 101-1018.

46. Janda JM, Bottone EJ, Skinner CV, Calcaterra D. Phenotypic markers associated with gastrointestinal Aeromonas hydrophila isolates from symptomatic children. J Clin Microbiol 1983; 17: 588-591.

47. Janda JM, Reitano M, Bottone EJ. Biotyping of Aeromonas isolates as a correlate to delineating a species-associated disease spectrum. J Clin Microbiol 1984; 19: 44-47.

48. Figura N, Marri L, Verdiani S, Ceccherin C, Barberi A. Prevalence, species differentiation and toxigenicity of Aeromonas strains in cases of childhood gastroenteritis and in controls. J Clin Microbiol 1986; 23: 595-599.

49. Shankar P, Agarwal RK, Sanyal SC. Experimental studies on enteropathogenicity of Vibrio cholerae serotypes other than non O1. Zentralbl Bakteriol Mikrobial Hyg A 1982; 252: 514-524.

50. Sanyal SC, Saraswathi B, Sharma P. Enteropathogenicity of Plesiomonas shigelloides. J Med Microbiol 1980; 13: 401-409.

51. Sanyal SC, Agarwal RK, Annapurna E, Lee JV. Enterotoxicity of group F vibrios. Jpn J Med Sci Biol 1980; 33: 217-222.

52. Sanyal SC, Huq MI, Neogy PKB et al. Vibrio mimicus as an aetiologic agent of diarrhoea and its pathogenesis. Indian $J$ Med Microbiol 1983; 1: 1-12.

53. Raychaudhury A, Agarwal RK, Sanyal SC. Enteropathogenicity of Klebsiella pneumoniae strains isolated from stools of diarrhoeal patients and other clinical specimens: an experimental study. Zentralbl Bakteriol Mikrobiol Hyg A 1984: 458: 94-103.

54. Singh SJ, Sanyal SC. Enterotoxicity of the so-called NAG vibrios. Ann Soc Belg Med Trop 1978; 58: 133-140. 